\title{
Fine-grained concrete with combined reinforcement by different types of fibers
}

\author{
Sergey Klyuev ${ }^{1, *}$, Alexander Klyuev ${ }^{1}$, and Nikolai Vatin ${ }^{2}$ \\ ${ }^{1}$ Belgorod State Technological University named after V.G. Shukhov, Belgorod, 308012, Russian \\ Federation \\ ${ }^{2}$ Peter the Great St.Petersburg Polytechnic University, St. Petersburg, 195251, Russian Federation
}

\begin{abstract}
The article deals with the application of combined reinforcement of fi-ne-grained concrete with steel wave and polypropylene fibers. High-density packaging of the mixture components was used to improve the strength and deformation characteristics. In order to reduce the cost of fibre concrete, composite binders were developed. Rational selection of filler and the use of a steel wave fiber gave the opportunity to get the fibre concrete with tensile compressive strength - 84.8 $\mathrm{MPa}$, the tensile strength in bending $-19.8 \mathrm{MPa}$ on technogenic sands of the Kursk Magnetic Anomaly. With combined reinforcement by steel and polypropylene fiber on technogenic sands of the Kursk magnetic anomaly fibre concrete with a tensile compressive strength $-82.8 \mathrm{MPa}$, in bending 19.1 MPa was developed. With the same strength charac-teristics the developed mixture of fibre concrete based on combined re-inforcement due to reducing the amount of steel fiber at cost is lower by $25 \%$ compared to the composition on steel fiber and the same com-posite binder.
\end{abstract}

\section{Introduction}

Dispersed reinforcement can be carried out as with one type of fiber, and with a mixture of different fibers with different parameters and significantly different in composition (for example, this article will consider the issue of combined reinforcement of fine-grained concrete by steel and propylene fiber). The use of dispersed reinforcement for reinforced concrete structures, in which part of the core reinforcement is replaced with fiber or eliminates it completely, is of prac-tical interest. Production of dispersed and reinforced composites and structures based on them depend to a large extent on the type of reinforcing materials (fibers) used for them [1 - 8].

At making dispersed and reinforced concrete, it is necessary to take into account the type of used concrete matrices. For the manufacture of dispersed and reinforced structures conventional heavy concrete with a limited size of coarse aggregate grains, cement-sand mortar, as well as cement or gypsum stone are used. In some cases, it is advisable to use lightweight concrete. The type of concrete determines the nature of the rational type of dispersed reinforcement and the optimal values of the geometric parameters of the dispersed reinforcement [9-15].

* Corresponding author: klyuyev@yandex.ru 
There are two fundamentally different types of matrices, reinforced by fibers: continuous re-inforcement, i.e. by long fibers, which are embedded in the matrix with such technologies as fil-ament winding or layering fiber layers; and individual short fibers, length less than $50 \mathrm{~mm}$, which are implemented into the matrix by spraying or mixing. Reinforcement of the matrix can be fur-ther classified according to the distribution of fibers in the matrix. Fibers continuous in shape can be set the desired orientation, which is controlled by the production process (winding orientation or direction of layering fibers) and the fiber layer structure. In the case of distributed fibers their distribution in the matrix is more uniformly and short fibers tend to take random orientation. However, even in these systems, fiber distribution is rarely completely uniform, and random fiber orientation is far from ideal [16-23].

\section{Materials and methods}

Research shows that the dispersed reinforcement provides an increase in the strength of the sections of compressed, stretched and bent structural elements, increases their fracture toughness, impact toughness, thermal resistance and other physical and mechanical properties. There are examples of successful application of dispersed and reinforced concrete in structures of various purposes: wall panels, floor slabs, tank bottoms, piles, pipes, trays of communication channels, floors of industrial buildings, road and airfield surfaces, permanent formwork for monolithic structures, etc. Dispersed reinforcement leads in some cases to a decrease in the material con-sumption of structures, cost and complexity of manufacturing compared to traditional solutions. This is achieved largely due to the partial or complete abandonment of the need for the use of traditional reinforcement meshes and frameworks in structures, as well as the result of the transfer in many cases of the complex production of reinforcement works in the process of manufacturing reinforced concrete mixture directly into the concrete mixer.

The main task in the production of fine-grained concretes, including dispersed and reinforced, is to reduce the consumption of the clinker component, as due to the lack of a large aggregate cement is overspending. The most significant factors of cement content reduction in dispersed and reinforced fine-grained concretes are: reduction of water demand in concrete mixture and increase of binder activity. Therefore, from this point of view, the use of composite binders is considered to be a promising direction to improve the efficiency of such concretes.

In the course of the study, binders of the following compositions were developed: finemilled cement binder (TMC-70) was obtained by threshing to the specific surface $\mathrm{Ssp}=500$ $\mathrm{m} 2 / \mathrm{kg}$ of Portland cement CEM I $42.5 \mathrm{~N}$ ac-cording to GOST 31108-2003.

Binder of low water demand (VNV-70) was obtained by co-threshing to a specific surface $500 \mathrm{~m} 2 / \mathrm{kg}$ of Portland cement CEM I $42.5 \mathrm{~N}$, quartzite sandstone crushing droupout and plasticiz-ing additive SP-1 in the optimal dosage.

\section{Results and discussion}

To assess the possibility of using the optimal type of fiber in the production of high-quality fine-grained fibre concrete compositions were developed, in which quartzite sandstone crushing dropout was used as filler. To optimize the structure of the matrix tavolzhansky sand was imple-mented in the composition of concrete.

In order to obtain high-quality fibre concrete, two types of fiber were implemented into the concrete matrix: steel wavy fiber, length $30 \mathrm{~mm}$, diameter $0.8 \mathrm{~mm}$; polypropylene fiber, length $6 \mathrm{~mm}$ (Fig. 1). 
a

b


Fig. 1. Fibers: $\mathrm{a}$ - steel wavy, $\mathrm{b}$ - polypropylene

To increase the uniformity of fiber-reinforced mixtures in the dry state, it is advisable to use pneumatic mixers. We developed and used a countercurrent pneumatic mixer presented in Fig. 2.
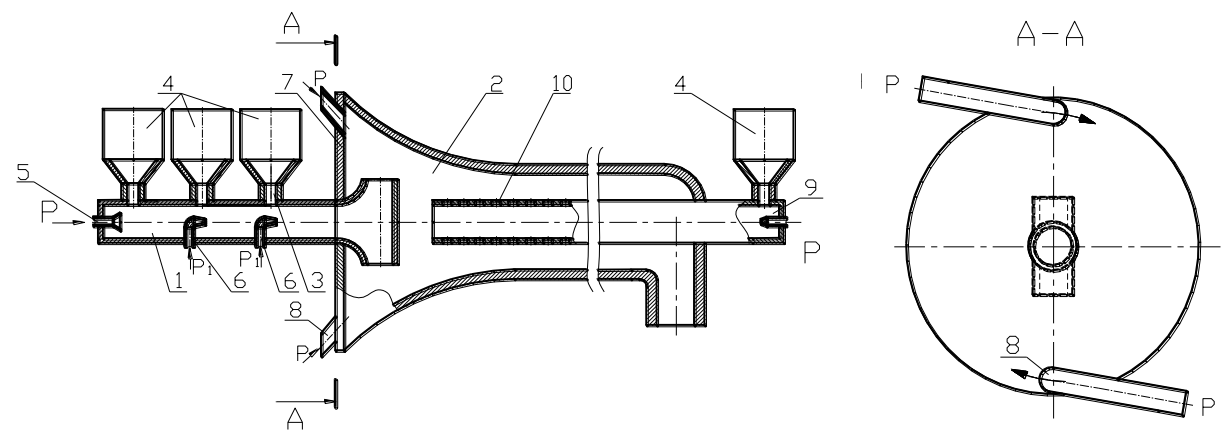

Fig. 2. Pneumatic mixer: 1 - feed pipe; 2 -closed torus; 3 - inlet pipe; 4 - hopper; 5,6,7 additional nozzles; 7 - butt; 8,9 - nozzles; 10 -hollow cylinder

The proposed construction is aimed at improving the quality of the fiber-based dispersed and reinforced mixture, which is achieved due to the technical effect, which is in improving the quality of the fluxing and mixing of the mixture components, obtained by using the countercurrent flow of the mixture components and ensuring the pressure difference in different zones of the pneumatic mixer.

With the aim of obtaining more high-strength fibre concrete experimental studies were conducted (tabl. 1)' where HDP is the high-density packing of grains of fine-grained fibre concrete.

The developed algorithm for calculating the multifunctional system "clinker-filleraggregate-organic additive-water" allowed varying the parameters of the concrete mixture in order to im-prove the composite performance. After studying and analyzing the experimental data obtained through the use of high-density packaging of grains, it can be concluded that these characteristics are increasing by $20-30 \%$.

The effect of high-density packaging of technogenic aggregate grains, enriched tavolzhansky natural sand, is achieved due to a more compact arrangement of all components, including steel fiber, and has a complex effect on the concrete mixture. So, in addition to the contacts "cement dough-aggregate", there are contacts "fiber-binder", the strength of which largely depends on the physical and chemical interaction of minerals that make up the aggregates and particles of the binder. 
Table 1. Physical and mechanical characteristics of fine-grained fibre concrete

\begin{tabular}{|c|c|c|c|c|c|c|c|c|}
\hline \multirow[b]{2}{*}{ 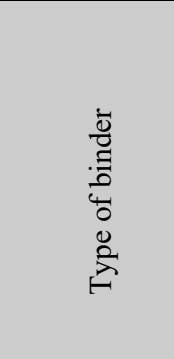 } & \multirow[b]{2}{*}{ 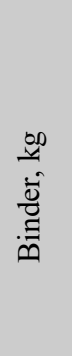 } & \multicolumn{4}{|c|}{$\mathcal{M}^{3}$ material consumption, $\mathrm{kg} /$} & \multirow[b]{2}{*}{ 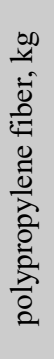 } & \multirow[b]{2}{*}{  } & \multirow[b]{2}{*}{ 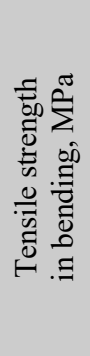 } \\
\hline & & 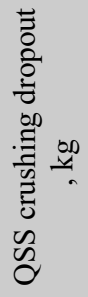 & 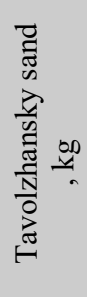 & $\begin{array}{l}\overrightarrow{\bar{\Delta}} \\
\vec{\pi} \\
3\end{array}$ & 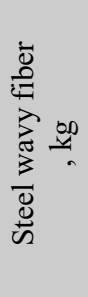 & & & \\
\hline Cem I $42.5 \mathrm{~N}$ & 510 & 1180 & 555 & 170 & - & - & 50.2 & 13.7 \\
\hline $\begin{array}{c}\text { Cem I } 42.5 \mathrm{~N} \\
* \mathrm{HDP} \\
\end{array}$ & 510 & 1185 & 555 & 172 & - & - & 56.5 & 14.2 \\
\hline Cem I $42.5 \mathrm{~N}$ & 510 & 1180 & 555 & 172 & 72 & - & 57.4 & 16.8 \\
\hline $\begin{array}{l}\text { Cem I 42.5N } \\
\text { *HDP }\end{array}$ & 510 & 1185 & 555 & 174 & 72 & - & 65.2 & 17.6 \\
\hline TMC-70 & 510 & 1180 & 555 & 160 & 72 & - & 63.4 & 17.4 \\
\hline $\begin{array}{l}\text { TC-70 } \\
* \text { HDP }\end{array}$ & 510 & 1185 & 555 & 162 & 72 & - & 69.7 & 18.2 \\
\hline VNV-70 & 510 & 1180 & 555 & 150 & 72 & - & 76.2 & 19.1 \\
\hline $\begin{array}{c}\text { VNV-70 } \\
\text { HDP }\end{array}$ & 510 & 1185 & 555 & 152 & 72 & - & 84.8 & 19.8 \\
\hline $\begin{array}{c}\text { VNV-70 } \\
\text { HDP }\end{array}$ & 510 & 1185 & 555 & 152 & 32 & 3 & 82.8 & 19.1 \\
\hline
\end{tabular}

The use of composite binders, such as TMC-70 and VNV-70, allows, in turn, improving the characteristics of concrete compared to similar compositions based on cement, which is explained by the denser structure of the cement stone of the composite binders and, consequently, the con-crete on their basis, as well as lower porosity.

\section{Conclusion}

Thus, high-density packaging of the mixture components based on composite binders has a directed effect on the structure formation of fibre concrete, allowing increasing the strength and deformation characteristics. Rational selection of filler and the use of steel wave fiber gave the opportunity to get the fibre concrete with tensile compressive strength- $84.8 \mathrm{MPa}$, tensile strength in bending - 19.8 MPa on technogenic sands of Kursk Magnetic Anomaly (Russia). With combined rein-forcement by steel and polypropylene fiber on technogenic sands of the Kursk magnetic anomaly fibre concrete with a tensile compressive strength 82.8 $\mathrm{MPa}$, in bending - 19.1 MPa was devel-oped. However, with the same strength characteristics the developed mixture of fibre concrete based on combined reinforcement due to reducing the amount of steel fiber at cost is lower by $25 \%$ compared to the composition on steel fiber and the same composite binder.

\section{References}

1. G. Wischers, Faserbewehrter Beton. Beton-Verlag. Düsseldorf, 95-99 (1975)

2. J.-D Wörner, Faserarten und - eigenschaften. Darmstädter Massivbau-Seminar. Darmstadt, 75-81 (1990)

3. Ch. Alfes, U. Wiens, Stahlfaserbeton nach DAfStb-Richtlinie. Beton, Heft 4, 128 135 (2010) 
4. Ch. Alfes, Qualitätssicherung von Stahlfaserbeton im Transportbetonwerk. BWI Betonwerk International Heft 6, 212-218 (2006)

5. P. Grübl, H. Weigler, S. Karl, Art Beton, Herstellung und Eigenschaften. Verlag Ernst \& Sohn, 98-112 (2001)

6. N.I. Vatin, Yu.G. Barabanshchikov, M.V. Komarinskiy, S.I. Smirnov, Mag. Civ. Eng. 56 (4), 1-10 (2015)

7. M.O. Dudin, N.I. Vatin, Y.G. Barabanshchikov, Mag. Civ. Eng. 54 (2), 33-45 (2015)

8. T.V. Dmitrieva, V.V. Strokova, A.A. Bezrodnykh, Construction Materials and Products. 1 (1), 69- 7 (2018)

9. S.V. Klyuev, A.V. Klyuev, A.D. Abakarov, E.S. Shorstova, N.G. Gafarova, Mag. Civ. Eng. 75 (7), 66-75 (2017)

10. S.V. Klyuyev, A.V. Klyuyev, D.M. Sopin, A.V. Netrebenko, S.A. Kazlitin, Mag. Civ. Eng. 38 (3), 7-14 (2013)

11. S.V. Klyuyev, Yu.V. Guryanov, Mag. Civ. Eng. 36 (1), 21-26 (2013)

12. V.A. Perfilov, Concrete Technology, 10 (87), 48-49 (2013)

13. M.Yu. Elistratkin, M.I. Kozhukhova, Construction Materials and Products. 1 (1), 59-68 (2018)

14. V.I. Morozov, Yu.V. Pukharenko, A.V. Yushin, Materials Physics and Mechanics, 31 (1-2), 40-43 (2017)

15. I.S. Zharikov, A. Laketich, N. Laketich, Construction Materials and Products. 1 (1), 51-58 (2018)

16. N.I. Karpenko, V.I. Travush, S.S. Kaprielov, A.V. Mishina, A.A. Andrianov, I.M. Bezgodov, Architecture and Construction, 1, 106-113 (2013)

17. L.Kh. Zagorodnyuk, V.S. Lesovik, D.A. Sumskoy, Construction Materials and Products, 1 (1), 40-50 (2018)

18. R.V. Lesovik, S.V. Klyuyev, A.V. Klyuyev, A.V. Netrebenko, A.V. Durachenko Research Journal of Applied Sciences, 9, 1153-1157 (2014)

19. S.V. Klyuev, T.A. Khezhev, Yu.V. Pukharenko, A.V. Klyuev, Mater. Sci. Forum, 931, 598-602 (2018)

20. S.V. Klyuev, T.A. Khezhev, Yu.V. Pukharenko, A.V. Klyuev, Mater. Sci. Forum, 931, 603-607 (2018)

21. B.S. Demyanova, V.I. Kalashnikov, G.N. Kazina, S.M. Sadenko, Building Materials. 9, 54-55 (2006)

22. T.A. Hezhev, A.V. Zhurtov, A.S. Tsipinov, S.V. Klyuev, Mag. Civ. Eng.. 80 (4), 181-194 (2018)

23. T.A. Khezhev, Yu.V. Pukharenko, Kh.A. Khezhev, S.V. Klyuev, ARPN Journal of Engineering and Applied Sciences. 13 (8), 2935-2946 (2018) 